Iqtishaduna, Vol. 12 No. 2 Desember 2021

pISSN 20879938 | eISSN 26559714

online: https://journal.uinmataram.ac.id/index.php/iqtishaduna

\title{
Comparison of Dividend Discount Model With Free Cash Flow To Firms For Valuation of Banking Stocks Listed in Jakarta Islamic Index (JII) Period 2016-2020
}

\author{
Hendra H. Dukalang ${ }^{1}$, Wiwin Koni ${ }^{2}$, Nhayu Cahya Mokoagow ${ }^{3}$ \\ IAIN Sultan Amai Gorontalo ${ }^{1,2,3}$ \\ hendra.statistika@iaingorontalo.ac.id
}

\begin{abstract}
This study aims to find out and analyze the fair value of stocks and stock conditions in banking companies using dividend discount model (DDM) and free cash flow to firms (FCFF) during the $2016-2020$ period. The population is in research in as many as 70 companies. Determination of samples with purposive sampling techniques, so that the samples obtained by 2 companies. The data used is secondary data and calculations by using Microsoft Excel 2016 application. The results showed that of the 2 banking companies listed in JII, bris and BTPS shares have different intrinsic values. Valuation Results using DDM show that the intrinsic value of BRIS Shares is in an Overvalued condition, for BTPS shares are undervalued. While the valuation result using FCFF obtained intrinsic value of BRIS shares is undervalued, for BTPS shares is in an Overvalued condition.
\end{abstract}

Keywords: Stock Price Valuation, Dividend Discount Model, Free Cash Flow to Firms

\section{INTRODUCTION}

In making investments there is a high level of risk and high profit. Stock prices are subject to change at any time, up and down the share price depending on the state of the economy at the time. Before making an investment an investor must conduct an analysis of the company/issuer he/she chooses. Stocks need to be assessed in order to know the performance of a company. Stock valuation needs to be done to find out if the company covers the stock at a market price against its intrinsic value aka fair value (fair valued) is in low condition (undervalued) or expensive (overvalued). The first thing an investor sees is the share price of the company, because knowing the share price can reflect the return of the invested capital. Basically investors buy shares for profit / dividends and when the shares are at higher price (capital gain) investors can sell them. Calculating fair valued stock price often uses Fundamental Analysis because it can directly inform important criteria in the company's financial performance as contained in the company's financial statements. In the technique using Fundamental Analysis is divided into 3 analysis, macroeconomic analysis, industrial analysis and company analysis. For company analysis, according to Damodaran (2002:13) three approaches that can be used are discounted cash flow approach, relative valuation, contingent claim, and liquidation and 
accounting valuation. This study will use a discount cash flow approach, which by calculating the discount of future cash flow using an overview of past performance. The discount cash flow approach itself consists of 3 methods, namely, Dividend Discount Model, Free Cash Flow to Firm, and Free Cash Flow to Equity. In this study, researchers only used DDM and FCFF methods.

\section{METHOD}

This is a descriptive and quantitative study using secondary data. Descriptive research is a study that is used to analyze data by describing the data that has been collected as it is without intending to generalize conclusions in general (Sugiyono, 2008). The techniques used in this study are fundamental techniques using dividend discount model (DDM) valuation, and Free Cash Flow to Firm (FCFF). With banking companies listed in the Jakarta Islamic Index.

Table 1. Number of samples with purposive sampling criteria

\begin{tabular}{cll}
\hline No. & \multicolumn{1}{c}{ Purposive Sampling } & \multicolumn{1}{c}{ sum } \\
\hline 1 & Companies listed in jii index for the period 2016-2020 & 30 Companies \\
\hline 2 & Reduced inconsistent company & 16 Companies \\
\hline 3 & $\begin{array}{l}\text { Reduced companies that are not included in the } \\
\text { banking sector }\end{array}$ & 14 Companies \\
\hline 4 & Total & 2 Companies \\
\hline
\end{tabular}

\section{Analyzing financial condition using financial ratios}

Calculating Earning Per Share (EPS)

$$
\text { EPS : } \frac{\text { Net Income }}{\text { Outstanding shares }}
$$

Calculating Dividen Per Share (DPS)

$$
\text { DPS : } \frac{\text { Dividen }}{\text { Outstanding shares }}
$$

Calculating Dividen Payout Ratio (DPR)

$$
D P R: \frac{D P S}{E P S}
$$

Calculating Return on Equity (ROE)

$$
\text { ROE }: \frac{\text { Net Income }}{\text { Shareholder's Equity }}
$$




\section{Calculating Dividend Discount Model (DDM)}

Calculating expected earning growth rate (g):

$$
\begin{gathered}
g=R O E \times b \\
=R O E \times(1-D P R)
\end{gathered}
$$

Source: Tendelilin (2010:376)

Information :

g = expected earning growth rate

ROE = Return On Equity observation period

b = retained earnings rate

DPR = Dividend Payout Ratio observation period

Determining the expected dividend estimate

$$
D_{1}=D_{0} \times(1+g)
$$

Source: Tambunan (2007:230)

\section{information :}

g = expected earning growth rate

$\mathrm{D}_{0} \quad=$ Dividend per Share

$\mathrm{D}_{1} \quad=$ estimated Dividend per Share

Specifying the expected return value (k)

$$
k=\frac{D_{1}}{P}+g
$$

Source: Brigham and Huston (2010:394)

information :

$\mathrm{k}=$ expected return

$\mathrm{D}_{1} \quad=$ estimated Dividend per Share

$\mathrm{P} \quad=$ stock price of the previous period

Calculating intrinsic values with the DDM method of constant growth

$$
P_{0}=\frac{D_{1}}{k-g}
$$

Source :Tendelilin (2010:308)

Information: 
$\mathrm{P} 0=$ intrinsic value using constant growth

D1 = estimated Dividend per Share

$\mathrm{K}=$ expected return

$\mathrm{g}=$ expected earning growth rate

3. Calculating Free Cash Flow to Firm (FCFF)

Calculating FCFF Values

$$
F C F F=E B I T x(1-\text { taxrate })+D A-C A P E X-W C
$$

Information :

FCFF $=$ Free Cash Flow to The Firm

$\mathrm{EBIT}=$ Earning Before Interest and Tax

Tax rate $=$ tax paid

$\mathrm{DA}=$ Amortization Depreciation

CAPEX $=$ Capital Expenditure

$\mathrm{WC}=$ Working Capital

Calculating Value Of Firm

$$
\text { Valueoffirm }=\frac{F C F F_{1}}{\left(W A C C-g_{n}\right)}
$$

Calculating Weighted Average Cost Of Capital (WACC)

$$
W A C C=[(\text { Dxrd })(1-\text { tax })+(\text { Exrd })]
$$

Which :

Capital Level (D) :

$$
D=\frac{\text { Liability }}{\text { Liability\&equity }} \times 100 \%
$$

Cost of Debt (rd) :

$$
r d=\frac{\text { Int expense }}{\text { Long Term Liability }} \times 100 \%
$$

Capital/Equity Level (E) : 


$$
E=\frac{\text { Equity }}{\text { Liability \& Equity }} \times 100 \%
$$

Cost Of Equity (re) :

$$
\text { re }=\frac{\text { Net Income }}{\text { Equity }} \times 100 \%
$$

Tax Rate :

$$
\text { tax }=\frac{\text { Tax Expense }}{\text { Income before tax }} \times 100 \%
$$

Calculating Total equity

$$
\text { total Equity }=\text { Value of firm }- \text { Liability }
$$

Calculating intrinsic values with the FCFF method

$$
\text { Intrinsic value }=\frac{\text { Equity }}{\text { Outstanding shares }}
$$

Source : Damodaran (2002:385)

\section{Making Investment Decisions}

Table 2. Investment Decision Making

\begin{tabular}{lcc}
\hline \multicolumn{1}{c}{ Information } & Stock Conditions & Investment Decisions \\
\hline Intrinsic Value $>$ Market Price & Undervalued & Buying Stocks \\
\hline Intrinsic Value < Market Price & Overvalued & Selling Shares \\
\hline Intrinsic Value = Market Price & Fair valued & Holding Stocks \\
\hline
\end{tabular}

\section{RESULTS AND DISCUSSION}

Valuation with Dividend Discount Model method Dividend Discounted Model (DDM) approach with a constant growth model (constant growth model). Calculations include several aspects, including growth, estimated cash dividend per share, expected rate of return, and intrinsic value determination. The calculation results can be seen in table 3 .

Table 3. DDM Method Share Price Valuation Results

\begin{tabular}{ccccc}
\hline & $\begin{array}{c}\text { Fair Value } \\
\text { (Rp) }\end{array}$ & $\begin{array}{c}\text { Market } \\
\text { Value (Rp) }\end{array}$ & Stock Conditions & Investment Decisions \\
\hline BRIS & 330 & 1.905 & Overvalue & sell \\
\hline BTPS & 4.250 & 2.900 & Undervalued & Hold / Buy \\
\hline
\end{tabular}

Source : data processed in 2021 
Based on the table above, BRIS shares are in an overvalued condition with investment decisions worth selling. Meanwhile, BTPS shares are undervalued with two investment decisions that are worth buying for investors who do not already own BTPS shares and held for investors who own BTPS shares to wait for the market value to rise and then be sold in order to gain capital gains. Valuation with Free Cash Flow to Firm method The intrinsic value of the shares can be identified after the total equity value has been obtained. The result of the reduction of value firm with total debt so that it will produce total equity. Value firm obtained by means of calculation of Free Cash Flow to Firm (FCFF) divided by wacc reduction and growth. The intrinsic value of shares is obtained from the distribution between the total equity and the number of shares outstanding each share. The intrinsic value of the stock for the entire sample can be seen in table 3. following.

Table 4. FCFF Method Stock Price Valuation Results

\begin{tabular}{ccccc}
\hline & $\begin{array}{c}\text { Fair Value } \\
(\mathbf{R p})\end{array}$ & $\begin{array}{c}\text { Market } \\
\text { Value (Rp) }\end{array}$ & Stock Conditions & Investment decisions \\
\hline BRIS & 26.309 & 1.905 & Undervalued & Hold/Buy \\
\hline BTPS & 1.272 & 2.900 & Overvalue & Sell \\
\hline
\end{tabular}

Source : data processed in 2021

Based on the table above, BRIS shares are undervalued with two investment decisions that are worth buying for investors who do not have BRIS shares and held for investors who own BRIS shares to wait for the market value to rise and then be sold in order to get capital gains. Meanwhile, BTPS shares are in an overvalued stock condition with investment decisions worth selling.

\section{CONCLUSION}

1. Based on the analysis that has been done using the dividend discount model (DDM) method, it is obtained that BRIS shares are in a condition of overvalued worth selling while BTPS is in a condition of undervalued worth buying or on hold.

2. Based on the analysis that has been done using the free cash flow to firm (FCFF) method, it is obtained that BRIS shares are undervalued or undervalued while BTPS shares are in an overvalued condition worth selling. 


\section{SUGGESTION}

For further researchers who want to discuss stock valuation using this method it is recommended to add free cash flow to equity method, also conduct accuracy test using Root Mean Squred Error (RMSE) to see the accuracy of calculations of the method used as well as add sample data.

\section{REFERENCES}

Afriani, E., \& Asma, R. (2019). Analisis Valuasi Harga Saham Dengan Price Earning Ratio, Free Cash Flow To Equity Dan Free Cash Flow To Firm Pada Perusahaan Manufaktur. Sains Manajemen Dan Kewirausahaan, 3(2), 111-123.

Bodie, Zvi, Alex Kane, Dan Alan J. Marcus. (2014). Manajemen Portfolio Dan Investasi. Edisi 9. Buku 2. Jakarta: Selemba Empat.

Darmadji Dan Fakhruddin. (2012). Pasar Modal Di Indonesia. Jakarta: Selemba Empat.

Emma Afriani, \& Asma, R. (2018). NalisisPenilaian Harga Saham Dengan Menggunakan PBV, FCFF Dan FCFE Pada Subsektor Tourism, Restaurant, Dan Hotel Yang Terdaftar Di Bursa Efek Indonesia Periode 2015-2017 Mika. Sains Manajemen Dan Kewirausahaan, 2(1), 51-60.

Florensi, V. (2019). Analisis Fundamental Saham-Saham Perusahaan Sektor Industri Barang Konsumsi Dengan Menggunakan Residual Income Model Dan Free Cash Flow Mode. $7(3), 6$.

Hendrawan, R., \&Rahayu, T. Z. (2020). Test Of FCFE Model And Dividend Discount Model In Book 4 Banking Companies Listed In Indonesia Stock Exchange. 117(Gcbme 2018), 142146. Https://Doi.Org/10.2991/Aebmr.K.200131.030

Hutapea, E. C., Poernomoputri, T. P., \& Sihombing, P. (2014). Analisis Valuasi Nilai Wajar Saham Pt. Adaro Energy Tbk Menggunakan Metode. Journal Of Applied Finance And Accounting, 5(2), 240- 270.

Kausari, I. (2019). Analisis Valuasi Harga Saham Dalam Pengambilan Keputusan Investasi Di Pasar Modal Syariah (Studi Pada Emiten Kontruksi Dan Bangunan Tahun 2014-2018). Https://Repository.Ar-Raniry.Ac.Id/Id/Eprint/13699/

Martia, D. Y., Wahyuni, M., Pinandhito, K., Semarang, P. N., Prof, J., Sh, S., \& Semarang, T. (2020). Penilaian Kewajaran Dan Pengambilan Keputusan Investasi Saham Pt Industri Jamu Dan Farmasi Sido MunculTbk. 3(1), 137-144. 
Noor, M. Sayyidin Dan Made DudySatyawan. (2014). Analisis Penilaian Harga Wajar Saham StudiKasus Pada PT Multi Bintang Indonesia Tbk. JurnalIlmuManajemen Volume, 2(3), 1098.

Sugiono. (2012). Metodelogi Penelitian Kuantitatif Kualitatif Dan R\&D.Bandung: Alfabeta

Tandelilin, Eduardus. (2017). Pasar Modal Manajemen Portfolio dan Investasi. Yogyakarta: Konisius.

Yuliah, Triana, L., \&Lesmana, I. S. (2019). Analisis Nilai Saham Dengan Dividend Discount Model (DDM) Program Studi Manajemen Universitas Bina Bangsa Abstrak Penilaian Saham Digunakan Untuk Membandingkan Antara Nilai Intrinsik Dan Nilai Pasar Saham, Yang Mana Akhirnya Akan Dijadikan Sebagai Da. 5(2), 9-13. 